Городецький Микола Ярославович кандидат економічних наук, Західноукраїнський національний університет, вул. Львівська, 11, м. Тернопіль, 46009, тел.: 067-208-35-08, https://orcid.org/0000-0003-4318-0999

Іванчук Світлана Іванівна кандидат економічних наук, доцент, доцент кафедри туризму, Національний транспортний університет, вул. М. Омеляновича-Павленка, 1, м. Київ, 01010, тел.: (044) 280-84-38, https:// orcid.org/0000-0002-7280-2344

Федоряк Руслан Михайлович кандидат економічних наук, доцент кафедри готельно - ресторанного бізнесу, Київський національний торговоекономічний університет, вул. Кіото, 19, м. Київ, 02156, тел.: (067) 888-37-91, https://orcid.org/0000-0002-6058-7443

\title{
ІННОВАЦІЙНИЙ РОЗВИТОК ТУРИСТИЧНОЇ ГАЛУЗІ В ПІСЛЯ ПАНДЕМІЧНИХ ПЕРЕТВОРЕНЬ
}

Анотація. В статті досліджується сучасний стан туризму в Україні. Визначено вплив пандеміï Covid19 на світовий туристичний ринок. Було досліджено основні економічні показники та встановлено їх спад, що було причиною логдаунів та закриття міжнародних кордонів. Так дослідження встановило, що частка міжнародного туризму впала на $20 \%$. Це є сучасна тенденція спаду, через Covid19. Макроекономічні показники характеризують стан економіки України в цілому і в 2021 році показники впали в 1,5 рази.

В статті визначені найбільш відвідувані об'єктів туристичного інтересу на території Європи в постковідний період. Зазначено, що у європейських країнах зосереджений досить потужний рекреаційний потенціал, а також найбільша кількість пам'яток i музеїв. Дослідження наукових праць та офіційних статистичних даних представлених в Конвенції про культурні цінності, визначенні ЮНЕСКО, а також класифікації видів мистецтва в цілому, виділено види туризму в Україні як пізнавальний, екскурсійний, паломницькій, оздоровчій, самодіяльний і т.д. Тому саме це дало підстави для визначення головних напрямів розвитку інноваційної діяльності туристичної галузі України.

Досліджено головні загрози та недоліки розвитку визначених напрямків туристичної діяльності на території України. Туризм виявився у своєрідному замкненому колі: низький рівень виробництва послуг, обумовлений слабкими інвестиціями в пам'ятки історії та культуру, веде до слабкого попиту i невеликому доходу, одержуваному в результаті надання цих послуг. 
Враховуючі данні проведеного критичного аналізу в статті запропоновані інноваційні напрямки розвитку туристичної галузі в після пандемічних перетвореннях України. Діяльність у галузі туризму, що $є$ інтеграційною складовою частиною національної економічної системи, повинна плануватися, спрямовуватися i координуватися комплексно, зачіпати всі аспекти його розвитку - правові, економічні, організаційні, соціальні, історико-культурні, науково-освітні, екологічні. Відзначається, що в кожному з цих напрямків має реалізовуватися свій інструментарій регулювання.

Ключові слова: туризм, інноваційні напрями, пандемія Covid19, туристична діяльність, туристичні послуги.

Horodetsky Mykola Yaroslavovych Candidate of Economic Sciences, West Ukrainian National University Ukraine, Lvivska St., 11, Ternopil, 46009, https://orcid.org/0000-0003-4318-0999

Ivanchuk Svitlana Ivanivna Candidate of Economic Sciences, Associate Professor, Associate Professor of the Department of Tourism, National Transport University, Ukraine, M. Omelyanovich-Pavlenko St., 1, Kyiv, 01010, tel.: (044) 280-84-38, https://orcid.org/0000-0002-7280-2344

Fedoryak Ruslan Mykhailovych Candidate of Economic Sciences, Associate Professor of the Department of Hotel and Restaurant Business, Kyiv National University of Trade and Economics, Kyoto St., 19, Kyiv, 02156, tel.: 067-888-37-91, https://orcid.org/0000-0002-6058-7443

\title{
INNOVATIVE DEVELOPMENT OF THE TOURISM INDUSTRY IN THE POST-PANDEMIC TRANSFORMATION
}

\begin{abstract}
The article examines the current state of tourism in Ukraine. The impact of the Covid19 pandemic on the world tourism market has been determined. Significant economic indicators were identified and declined, leading to quarantines and the closure of international borders. Thus, the study found that the share of international tourism fell by $20 \%$. This is a current downward trend, due to Covid19. Macroeconomic indicators characterize the state of Ukraine's economy as a whole and in 2021 the indicators fell by 2 times. The article identifies the most visited tourist attractions in Europe in the post-war period. It is noted that European countries have a strong recreational potential, as well as the largest number of monuments and museums. Research of scientific works and official statistics presented in the Convention on Cultural Property, UNESCO definition, as well as the classification of arts in general, highlighted the types of tourism in Ukraine as cognitive, sightseeing, pilgrimage, health, amateur, etc. Therefore, this gave grounds for determining the main directions of development of innovation in the tourism industry of Ukraine.
\end{abstract}


The main threats and shortcomings of the development of certain areas of tourism in Ukraine have been studied. Tourism has found itself in a vicious circle: low levels of production of services due to weak investment in historical and cultural monuments, leads to weak demand and low income from the provision of these services.

Taking into account the critical analysis in the article, innovative directions of development of the tourism industry in the post-pandemic transformations of Ukraine are proposed. Activities in the field of tourism, which is an integral part of the national economic system, should be planned, directed and coordinated comprehensively, affect all aspects of its development - legal, economic, organizational, social, historical, cultural, scientific, educational, environmental. It is noted that in each of these areas should be implemented its own regulatory tools.

Keywords: tourism, innovative directions, Covid19 pandemic, tourist activity, tourist services

Постановка проблеми. Ефективний розвиток туристичної галузі сприятиме покращенню загалом економіки країни, оскільки стимулюватиме розвиток інших галузей господарства, збільшить кількість робочих місць i відрахування до бюджету. У світі туристичну галузь вважають такою, що найбільше постраждала від карантинних заходів та від поширення інфекції. Так, щорічний потік туристів у світі, який оцінюють у 1,4 мільярда осіб[1], цього року, за попередніми оцінками, зменшилась в півтора рази, такі розрахунки наводить ООН.

Проблеми актуальні і для підприємств операторів туристичного ринку, що не зважаючи на високий рівень конкуренції в середині галузі, здійснюють активну інноваційну діяльність та забезпечують споживачів на ринку подорожей України своїми професійними різноманітними послугами у тому числі екскурсійного характеру. Тому дослідження проблем в туристичній галузі $\epsilon$ актуальною, тим саме якщо враховувати пандемічні перетворення в світі.

Аналіз останніх досліджень і публікацій. У науковій літературі вже накопичений певний досвід в дослідженні туристичної діяльності та стратегічного планування підприємств. Зокрема значний внесок зроблений такими авторами, як Г. Долженко, Б. Емельянов, Т. Ішекова, В. Федоренко, О. Костюкова, Т. Дьорова, М. Олексієнко, В. Сенін, Т. Сокол, Н. Гасюк, М. Головатий, Р. Красій, В. Передерко, О. Дюжник, І. Ансофф, А. Томпсон, А.Дж. Стрікленд, Ш. Остер, Б. Хендерсон, А. Бєлошапка, С. Покропивний, В. Колот, В. Пастухова, А. Наливайко, З. Шершньова, М. Портер, М. Бойко, М. Борущак, В. Герасименко, Н. Коніщева, О. Любіцева, М. Мальська, В. Мамутов, Г. Михайліченко, А. Панасюк, В. Руденко, О. Самко, Т. Ткаченко, Л. Шевчук та ін. Сучасному розвитку та перебудови на ринку туристичних послуг в постковідний період присвячені праці таких науковців: Басюк Д. I., Бойко Г.Ф., Воронкова Т. С., Іванчук С.І., Компанець К.А., Кошівська М.В., Мельник Л. В., Притуленко А. В., Рахман М. С., Уліганець С. І., 
Хмелевський О.В. та інші. Але питання залишається досить не достатньо досліджено, так як не врахований міжнародний досвід країн світу які теж опинились в пандемічних обмеженнях. Тому стає питання визначення та встановлення напрямів інноваційного розвитку туристичної галузі України сучасний світовий стан.

Мета статті - теоретико-методичне визначення напрямків інноваційного розвитку туристичної галузі в після пандемічних перетвореннях

Виклад основного матеріалу. На сучасному етапі свого розвитку людство розвивається стрімкими темпами, а отже й вимоги до задоволення потреб життєдіяльності людини також збільшуються. Це стосується в тому числі й сфери туризму. Обираючи країну відпочинку, люди прагнуть не лише споглядати памятки архітектури, а й задовольняти умови свого перебування в місцях відпочинку[1].

На даний час виділяють внутрішній i міжнародний туризм, причому внутрішній туризм за ступенем охоплення домінує над міжнародним. На частку внутрішнього туризму припадає 75-80\% загальної кількості туристів у світі, відповідно за фінансовими результатами у багатьох країнах він значно перевищує іноземний. Дослідження науковців свідчать, що стан світової індустрії туризму, незважаючи на об'єктивні труднощі останніх років, в цілому демонструє стабільність і зберігає позиції найбільшого і високоприбуткового сектора світової економіки. Розвиток міжнародного туризму зазвичай дуже сприйнятливий до економічних змін. За розрахунками, при відносній сталості рівня цін приріст на $1 \%$ реального особистого споживання призводить до зупинки зростання витрат на подорожі; при прирості споживання на 2,5\% витрати на туризм зростають на 4\%, а при прирості споживання на 5\% - на 10\%. У будь-якому випадку, якщо приріст споживання нижче $1 \%$, то туризм зазвичай відчуває спад [2].

Дослідники сучасності встановлюють, що частка міжнародного туризму впаде ще на 20\%. Це є сучасна тенденція спаду, через Covid19. Макроекономічні показники характеризують стан економіки країни в цілому. Центральним i найважливішим макроекономічним показником $\epsilon$ валовий внутрішній продукт (ВВП). Він розглядається в якості найбільш загального індикатора рівня економічного розвитку і добробуту країни.

Існує тісний зв'язок між зростанням міжнародного туризму і загальними тенденціями розвитку економіки України. Якщо туризм $є$ потужним локомотивом економічного зростання, то розвиток туризму, в кінцевому рахунку, визначається сукупним економічним потенціалом країни [3]. Оскільки, економічне зростання - це збільшення розмірів реального ВВП одного періоду порівняно 3 іншим, слід розглянути його динаміку (табл. 1). 
Таблиия 1

Динаміка ВВП і частки туристичного сектору України за 2013-2020pp.

\begin{tabular}{|l|l|l|l|l|l|l|l|l|}
\hline Показники & $\mathbf{2 0 1 3}$ & $\mathbf{2 0 1 4}$ & $\mathbf{2 0 1 5}$ & $\mathbf{2 0 1 6}$ & $\mathbf{2 0 1 7}$ & $\mathbf{2 0 1 8}$ & $\mathbf{2 0 1 9}$ & $\mathbf{2 0 2 0}$ \\
\hline $\begin{array}{l}\text { Номінальний } \\
\text { ВВП, млрд. } \\
\text { грн. }\end{array}$ & $\begin{array}{l}1454, \\
\text { Темп росту }\end{array}$ & $\begin{array}{l}1566, \\
10,3\end{array}$ & $\begin{array}{l}1979, \\
5\end{array}$ & $\begin{array}{l}2383, \\
1\end{array}$ & $\begin{array}{l}2982, \\
9\end{array}$ & $\begin{array}{l}3558, \\
7\end{array}$ & $\begin{array}{l}3974,5 \\
6\end{array}$ & $\begin{array}{l}4194, \\
1\end{array}$ \\
\hline $\begin{array}{l}\text { номінального } \\
\text { ВВП, у \% }\end{array}$ & 10,7 & 12,3 & 12,4 & 12,2 & 11,9 & 11,7 & 5,5 \\
\hline $\begin{array}{l}\text { Реальний } \\
\text { ВВП, у \% до } \\
\text { попереднього } \\
\text { року }\end{array}$ & 10,8 & 9,3 & 9,2 & 10,3 & 10,3 & 10,3 & 10,3 & 9,8 \\
\hline $\begin{array}{l}\text { Частка } \\
\begin{array}{l}\text { туристичного } \\
\text { сектора у у } \\
\text { ВВП,\% }\end{array}\end{array}$ & 2,1 & 1,5 & 1,4 & 1,5 & 1,5 & 1,4 & 1,4 & 1.2 \\
\hline
\end{tabular}

Джерело: сформовано авторами на підставі [4]

Зрозуміло, що така ситуація спричинена сучасними умовами впливу пандемії. Але туризм залишається основним сектором прибутків держави.

Цим пояснюється підвищений інтерес до сфери туризму з боку урядів більшості країн світу, що мають структури виконавчої влади для забезпечення ефективної державної політики його розвитку. У найближчі роки туристські ринки розвинених країн будуть стабільно зростати внаслідок збільшення доступності туризму для більш широких верств суспільства i частоти туристських поїздок.

За останне століття туризм перетворився 3 короткочасних мандрівок у потужну високорентабельну індустрію, величезний комплекс, у якому тісно переплелися економічні і соціальні інтереси. В економіці найбільш розвинених країн Західної Свропи та Америки ця галузь посідає одне з чільних місць за обсягами доходів, кількістю створених робочих місць, надходжень до бюджету. Завдяки стрімким темпам зростання вже наприкінці минулого та на початку XXI століття туристична галузь стала лідером світової економіки. Про це свідчать такі показники: на частку туризму припадає близько $12 \%$ світового валового продукту, понад $30 \%$ обсягів послуг світової торгівлі, $11 \%$ світових споживчих витрат, 7\% загального обсягу інвестицій та 5 \% податкових надходжень. Сьогодні у сфері туристських послуг зайнятий кожен десятий працівник, це понад 260 млн. осіб[5].

Для нових туристських ринків та тих, що розвиваються характерні тенденції збереження динамічного зростання і відповідного збільшення бюджетних надходжень на найближче десятиліття. Очікується поступове 
зміщення акцентів у розвитку туризму від традиційних ринків Західної Європи, США, Японії та Канади до альтернативних ринків таких, як Центральна та Східна Європа, Китай, Південна Корея, Мексика, а також деякі країни Близького Сходу.

До найбільш відвідуваних об’єктів туристичного інтересу на території сучасної Європи, за останніми даними Всесвітньої туристичної організації, належать: Ейфелева вежа (Париж, Франція) -7 млн. туристів за рік; Лувр (Париж, Франція) - 8,8 млн. туристів за рік; Собор Святого Петра (Рим, Італія) - 10,1 млн. туристів за рік; Базиліка Сакре-Кер, «Базиліка святого Серця» (Париж, Франція) - 10,5 млн. туристів за рік; Діснейленд (Париж, Франція) - 12,5 млн. туристів за рік; Собор Паризької Богоматері (Париж, Франція) - 13,5 млн. туристів за рік; Критий ринок («Гранд-базар») (Стамбул, Туреччина) - 15 млн. туристів за рік [6] Поряд 3 цим доцільно зазначити, що культурно пізнавальний туризм надзвичайно розвинутий i в США, куди щорічно приїжджають понад 50 млн. туристів. У цій країні зосереджений досить потужний рекреаційний потенціал, а також найбільша кількість пам'яток і музеїв. Специфічним напрямом пізнавальних подорожей у цьому регіоні є етнографічні екскурсії, які включають в себе відвідування місць первісного проживання , це, значна частина країни досі залишається невідомою для туристів" [7].

За даними Держприкордонслужби, найчастіше в Україну приїжджають туристи з Росії, Польщі, Білорусі, Німеччини, США, Італії, Румунії, Туреччини, Великобританії, Ізраїлю, Словаччини і Угорщини. За даними Всесвітньої туристичної організації (ВТО), Україна в 2021 р. знову увійшла у ТОП-20 країн, які користуються найбільшою популярністю серед туристів, та посіла чотирнадцяту позицію у цьому рейтингу. Організація оприлюднила рейтинг найбільш відвідуваних туристами країн, перше місце у якому посіла Франція, а Україна 3 показником у 21.400 .000 млн. туристів розмістилася на 14-й сходинці [8].

За даними Державної прикордонної служби, в першому кварталі нинішнього року з туристичною метою Україну відвідало 3,35 мільйона іноземців, що на 17\% менше, ніж у цей же період торік. Гості з-за кордону тепер частіше приїздять до Львова, Івано-Франківська, значно рідше - до Києва. Проте, для тих, хто все ж відвідує столицю, «туристичними Мекками»є Майдан і та «Межигір'я» [9].

У результаті на міжнародному, національному та регіональних рівнях стали розроблятися стратегії якісної зміни та вдосконалення туристичної галузі, причому ефективність даних документів визначатиметься ступенем їх узгодженості на різних рівнях планування. На тлі все більшого зростання ролі туризму в світі, сучасний розвиток вітчизняного туризму характеризується наявністю глибоких протиріч. 
Однією з найбільш значущих тенденцій розвитку світового туризму є різке посилення конкуренції на ринку туристичної пропозиції, як наслідок поява все більшого числа країн 3 амбітними планами залучення туристів, а також перенасичення на ринку однотипних туристських пропозицій. У результаті, країни, що прагнуть зберегти або зміцнити свої позиції на міжнародному ринку, здійснюють планування туризму на основі принципів сталого розвитку, передбачають довгострокові інвестиції в дану сферу і мають чіткі державні стратегії розвитку туризму.

Хоча екскурсійна діяльність в Україні історично розвивалася великими темпами, але сучасний економічний та політичний стан України приводить до негативної ситуації у сфері і характеризується такими основними ознаками:

- відсутністю ефективної системи захисту прав та інтересів екскурсантів, забезпечення безпечних умов на об’єктах туристсько-екскурсійних відвідувань та за напрямами екскурсійних маршрутів;

- відсутністю сприятливих умов для розвитку екскурсійної справи, державної інвестиційної політики у цій сфері та належної їі підтримки;

- практичною недоступністю якісного екскурсійного обслуговування для малозабезпечених верств населення, дітей, молоді, осіб похилого віку та 3 особливими потребами;

- відсутністю необхідної кількості професійних фахівців туристичного супроводу (екскурсоводів та гідів-перекладачів);

- відсутністю міського екскурсійно-методичного центру (ради), який би перевіряв професійні навички та знання фахівців туристичного супроводу, розробляв методики їх підготовки/перепідготовки та ін.

- практичною відсутністю місць паркування чи короткочасної зупинки екскурсійних автобусів біля об’єктів екскурсійного показу;

- відсутністю окремої дорожньої смуги для екскурсійного автотранспорту, що заважає впровадженню міських автобусних екскурсій із застосуванням багатомовної лінгафонної системи;

- відсутністю розвинутої мережі туристсько - інформаційних центрів та екскурсійних пунктів;

- відсутністю чіткої схеми підготовки та перепідготовки відповідних кадрів, їх категоризації й акредитації;

- відсутністю системи обов’язкового страхування екскурсантів;

- на належному рівні не здійснюється популяризація екскурсійної діяльності як важливого складника в духовному збагаченні населення, вихованні підростаючого покоління [10].

Відповідно, підвищується роль державної політики розвитку туризму країни в цілому, а також цільового просування окремих туристських продуктів на вітчизняному та міжнародному ринках. Туризм як галузь одна 3 перших піддалася негативному впливу кризи. В умовах нестабільності економічної 
ситуації та скорочення доходів населення вважає за краще знизити витрати в першу чергу на відпочинок і подорожі.

На підставі даних представлених в Конвенції про культурні цінності, визначенні ЮНЕСКО, а також класифікації видів мистецтва в цілому, доцільно виділити такі види туризму в Україні як пізнавальний, екскурсійний, паломницькій, оздоровчій, самодіяльний і т.д. Тобто до цих видів туризму належать пізнання туристів культурних цінностей незалежно від їх походження.

Виходячи 3 проведеного дослідження можемо виділити інноваційні напрямки розвитку туристичної діяльності в Україні, що представимо на рис.1. 
Інноваційні напрями розвитку туризму в Україні

Туризм орієнтований на ознайомлення з культурними цінностями

\section{$\checkmark$}

Туризм орієнтований на ознайомлення з рухомими культурними цінностями релігійного або світського характеру

Туризм, орієнтований на ознайомлення з культурною спадщиною

$\checkmark$

Туризм, орієнтований на ознайомлення 3 культурною спадщиною, до якої відносяться: твори монументальної скульптури і живопису, елементи або структури археологічного характеру, написи, печерні житла і групи елементів, які мають видатну універсальну цінність з точки зору історії, мистецтва або науки; ансамблі

Туризм, орієнтований на ознайомлення з природною спадщиною

Туризм, орієнтований на ознайомлення $з$ підводною культурною спадщиною, до якої відносяться: усі сліди людського існування, що мають культурний, історичний, археологічний характер, які частково або повністю, періодично або постійно знаходяться під водою протягом не менше 100 років

$\downarrow$

Туризм, орієнтований на проведення археологічних розкопок

Туризм, орієнтований на ознайомлення і вивчення сукупності елементів, що представляють культурну цінність, у тому чисті: колекції предметів мистецтва, що зберігаються в музеях, колекції предметів історії, науки і техніки, ботанічні і зоологічні сади, акваріуми.

Туризм, орієнтований на ознайомлення і вивчення процесів, що зберігають красу i характер пейзажів і місцевостей, створених як природою, так і працею людини.

\section{$\downarrow$}

Туризм, орієнтований на ознайомлення i вивчення умов збереження історичних і традиційних ансамблів.

Puc. 1. Інновачійні напрями розвитку туризму в Украйні

Джсерело: сформовано авторами

Тобто наразі в сучасних постковідних умовах необхідний напрямок розвитку туризму в Україні є пізнавальний туризм, рекреаційний та екскурсійний. Саме ці види туризму $є$ найбільш масовим і охоплюють біля 3/4 всіх туристів світу.

Висновки. Вирішення одного 3 ключових завдань розвитку вітчизняного туризму вимагає здійснення масштабних інвестицій. Однак у цьому відношенні 
український пізнавальний туризм виявився у своєрідному замкненому колі: низький рівень виробництва послуг, обумовлений слабкими інвестиціями в пам'ятки історії та культуру, веде до слабкого попиту і невеликому доходу, одержуваному в результаті надання цих послуг. Невеликий прибуток i, як наслідок, невеликі грошові накопичення ведуть до слабких інвестицій в індустрію туризму.

Діяльність у галузі туризму, що є інтеграційною складовою частиною національної економічної системи, повинна плануватися, спрямовуватися i координуватися комплексно, зачіпати всі аспекти його розвитку - правові, економічні, організаційні, соціальні, історико-культурні, науково-освітні, екологічні. Відзначається, що в кожному з цих напрямків має реалізовуватися свій інструментарій регулювання.

\section{Лimepamypa:}

1.Компанець К.А., Іванчук С.І. Вплив інвестицій на розвиток туристичної галузі України. Вісник НТУ Вісник Національного транспортного університету - Випуск № 43 2018. URL: http://publications.ntu.edu.ua/visnyk/41/049.pdf ( дата звернення:20.12.2021)

2.Внутрішній туризм в Україні - на підйомі через COVID-19. Чи надовго?. Радіо свобода. URL:https://www.radiosvoboda.org/a/vnytrishniy-turyzm-v-ukraini-covid19/ 30726545.html (дата звернення:10.01.2022)

3. Воронкова Т.Є., Притуленко А.В. Міжнародний туризм і його вплив на соціальноекономічний розвиток України. Ефективна економіка. 2020. DOI: 10.32702/23072105-2020.11.83

4. Офіційний сайт Державного комітету статистики України. URL: http://www.ukrstat.gov.ua/. (дата звернення:10.01.2022)

5. COVID-19 RESPONSE: $96 \%$ of global destinations impose travel restrictions, World Tourism Organization (UNWTO) reports. URL: https://www.unwto.org/news/covid-19-responsetravel-restrictions (дата звернення:13.01.2022)

6. Хмелевський О.В., Кошівська М.В. Розвиток туризму в контексті євроінтеграції України. Приазовський економічний вісник. 2018. С. 15-21 URL: http://pev.kpu.zp.ua/journals/2018/2_07_ uk/5.pdf (дата звернення: 13.01.2022)

7. Країни світу. Міжнародний туризм. Україна туристична. URL: http://svit.ukrinform.ua/turism.php?page=ukr_tur\&id=23762. (дата звернення:10.01.2022)

8. Рахман М. С. Кон'юнктурний аналіз розвитку готельної індустрії як складової туризму України. Бізнес Інформ. 2015. № 11. С. 205-211

9. Уліганець С. І., Басюк Д. І., Мельник Л. В. Значення туристичного іміджу для розвитку Закарпатської області. Географія та туризм. 2013. Вип. 24. С. 162-173

10. Бойко Г.Ф. Компанець К.А. Методичні підходи до формування туристичного продукту (маршруту). URL: http://www.market-infr.od.ua/journals/2018/18_2018_ukr/11.pdf (дата звернення:13.01.2022)

\section{References:}

1. Kompanets K.A., Ivanchuk S.I. (2018) Vplyv investytsii na rozvytok turystychnoi haluzi Ukrainy [The impact of investment on the development of the tourism industry of Ukraine]. Bulletin of NTU Bulletin of the National Transport University - Issue № 43 - 2018. http://publications.ntu.edu.ua/visnyk/41/049.pdf [in Ukrainian]. 
2. Vnutrishnii turyzm v Ukraini - na pidiomi cherez COVID-19. Chy nadovho?. [Domestic tourism in Ukraine is on the rise through COVID-19] How long ?]. Radio Liberty. https://www.radiosvoboda.org/ a/vnytrishniy-turyzm-v-ukraini-covid19/30726545.html [in Ukrainian].

3. Voronkova T.E., Pritulenko A.V. Mizhnarodnyi turyzm i yoho vplyv na sotsialnoekonomichnyi rozvytok Ukrainy. [International tourism and its impact on the socio-economic development of Ukraine] Efficient economy. 2020. DOI: 10.32702/2307-2105-2020.11.83 [in Ukrainian].

4. Ofitsiinyi sait Derzhavnoho komitetu statystyky Ukrainy. [Official site of the State Statistics Committee of Ukraine]. URL: http://www.ukrstat.gov.ua/. [in Ukrainian].

5. COVID-19 RESPONSE: $96 \%$ of global destinations impose travel restrictions [COVID-19 RESPONSE: $96 \%$ of global destinations impose travel restrictions] World Tourism Organization (UNWTO) reports. URL: https://www.unwto.org/news/covid-19-response-travel-restrictions [in Ukrainian].

6. Khmelevsky O.V., Koshivskaya M.V. Rozvytok turyzmu v konteksti yevrointehratsii Ukrainy. [Tourism development in the context of Ukraine's] European integration. Priazovsky Economic Bulletin. 2018. C. 15-21 URL: http://pev.kpu.zp.ua/journals/2018/2_07_uk/5.pdf [in Ukrainian].

7. Krainy svitu. Mizhnarodnyi turyzm. Ukraina turystychna. [Countries of the world. International tourism]. Ukraine is tourist. URL: http://svit.ukrinform.ua/turism. php? page = ukr_tur $\& \mathrm{id}=23762$. [in Ukrainian].

8. Rakhman M.S. Koniunkturnyi analiz rozvytku hotelnoi industrii yak skladovoi turyzmu Ukrainy. [Conjuncture analysis of the hotel industry as a component of tourism in Ukraine]. Business Inform. 2015. № 11. S. 205-211[in Ukrainian].

9. Uliganets S.I., Basyuk D.I., Melnyk L.V. Znachennia turystychnoho imidzhu dlia rozvytku Zakarpatskoi oblasti. [The importance of tourist image for the development of the Transcarpathian region]. Geography and tourism. 2013. Vip. 24. pp. 162-173[in Ukrainian].

10. Boiko G.F., Kompanets K.A.(2018) Metodychni pidkhody do formuvannia turystychnoho produktu (marshrutu). [Methodical approaches to the formation of a tourist product (route). http://www.market-infr.od.ua/journals/2018/18_2018_ukr/11.pdf[in Ukrainian]. 